\title{
Phosphorus mobility in a karst landscape under pasture grazing system
}

\author{
G.A. ALLOUSH ${ }^{\mathrm{a}}$, D.G. BOYER**, D.P. BELESKY ${ }^{\mathrm{b}}$, J.J. HALVORSON ${ }^{\mathrm{b}}$ \\ ${ }^{\text {a }}$ Virginia Tech, Department of Crop and Soil Environmental Sciences, 418 Smyth Hall (0403), Blacksburg, VA 24061, USA \\ ${ }^{\mathrm{b}}$ USDA-ARS, Appalachian Farming System Research Center, 1224 Airport Road, Beaver, WV 25813, USA
}

(Received 23 April 2002; accepted 21 March 2003)

\begin{abstract}
The spatial distribution and partitioning of water dissolved phosphorus fractions in the soil profile of a grazed karst sinkhole landscape were investigated. We also measured $\mathrm{P}$ fractions in surface runoff entering a sinkhole drain and in karst spring flow draining the study area. Grazing increased total N, C, and all forms of P of soil. Dissolved inorganic orthophosphate (DPi) was the highest in the surface soil layer and diminished significantly with depth. The proportion of dissolved unreactive phosphorus (DPu) increased with soil depth. Changes in DPu with landscape position and depth were closely correlated with changes in dissolved organic carbon (DOC) suggesting that the mobility and transport of DPu was mediated by DOC. Landscape position sampling showed molybdate reactive phosphorus (MRP) and DPu increased toward the bottom and center of sinkholes. The distribution of DPi and DPu in surface runoff and that occurring in underground watercourses confirms the significance of DPu transported into karst groundwater.
\end{abstract}

phosphorus transport / dissolved unreactive phosphorus / molybdate reactive phosphorus / karst / grazing impacts

Résumé - Mobilité du phosphore dans une zone karstique paturée. La distribution spatiale et la partition des fractions de phosphore dissoutes dans le profil de sol d'un paysage pâturé de dolines karstiques ont été étudiées. Nous avons également mesuré les fractions de P dans les eaux de surface entrant dans un drain de doline et dans l'écoulement ressortant du karst drainant le secteur d'étude. Le pâturage a augmenté $\mathrm{N}$ total, C, et toutes les formes de $\mathrm{P}$ de sol. L'orthophosphore inorganique dissous (DPi) était le plus élevé dans la couche de surface du sol et réduit significativement avec la profondeur. La proportion de phosphore non réactif dissous (DPu) a augmenté avec la profondeur de sol. Des changements de DPu en fonction de la position dans le paysage et de la profondeur ont été étroitement corrélés avec des changements du carbone organique dissous (DOC) suggérant que la mobilité et le transport du DPu ont été facilités par le DOC. Un échantillonnage dans le paysage a montré une augmentation de phosphore réactif au molybdate (MRP) et de DPu vers le fond et le centre des dolines. La distribution de DPi et DPu dans l'écoulement de surface et ce qui se produit lors du transit de l'eau sous terre confirme la valeur significative du DPu transporté dans les eaux souterraines du karst.

transport de phosphore / phosphore dissous non réactif / phosphore réactif au molybdate / karst / impacts du pâturage

\section{INTRODUCTION}

The strong positive correlation between concentrations of total dissolved phosphorus $(\mathrm{P})$ in Appalachian rivers and the percent of their watershed areas classified as karst landscape [35] emphasizes the need to understand $P$ dynamics in the Appalachian region. Cattle dung deposited in pasture by grazing animals results in localized soil $\mathrm{P}$ accumulation that can exceed plant requirements and has the potential to enrich surface runoff and sub-surface waters with P. Phosphorus moves across and through the soil as water-soluble and sedimentbound $\mathrm{P}$ forms $[24,28]$. Because sinkholes can funnel surface runoff into subsurface drainage ways, understanding the spatial distribution and forms of soil $\mathrm{P}$ within karst landscapes represents a first step in identifying non-point source $\mathrm{P}$ transport processes. Such information may help producers develop and apply appropriate grazing management practices that minimize nutrient movement into ground water.

In most cases, surface soil is the phosphorus-rich zone to which fertilizers and animal manure are applied [19]. It is also the soil zone, only a few millimeters in depth, where interactions with rain influence water quality [26]. Organic $\mathrm{P}(\mathrm{Po})$, which is highly variable, accounts, on average, for $50 \%$ of

Communicated by Gérard Guyot (Avignon, France)

* Corresponding author: dboyer@afsrc.ars.usda.gov 
total $\mathrm{P}$ in surface soil [22], and may influence forms of mobile $\mathrm{P}$ in soil and water. Recent studies $[3,20]$ showed that application of animal manure increased $\mathrm{P}$ mobility and that leaching of Po was greater than that of inorganic P (Pi). It was also shown in soil solution of grasslands/manured soils $[3,8,11$, $23,25]$ that Po was likely to become a higher percentage (70$90 \%$ ) of total P (TP) in deeper soil layers $[6,17,27]$ due to a decrease in molybdate reactive $\mathrm{P}(\mathrm{MRP})$. These studies agree with long-term field observations from Rothamsted Experimental Station [14] suggesting that manure applications to grasslands increased P levels below $30 \mathrm{~cm}$ in the soil.

Organic phosphorus has been demonstrated to be transferred to surface waters in substantial amounts [4], where it can contribute to algal growth after release of inorganic phosphorus by phosphatase enzymes [34]. The release of organic phosphorus in different soil types and agricultural systems increases with wetting and drying of the soil $[33,34]$. The various $\mathrm{P}$ forms differ markedly in their potential to be transferred from the soil and their availability to algae in surface waters. Espinosa et al. [10] detected a range of $P$ species in soil leachate water, which included orthophosphate, inositol hexaphosphate, glucose-6phosphate, adenosine 5-triphosphate, phosphonates and other as yet unidentified forms of $P$.

We investigated the influence of grazing and spatial variability occurring across sinkholes on water extractable $\mathrm{P}$ fractions, forms and distribution in the top $20-\mathrm{cm}$ of soil in a fractured and porous karst landscape where direct contact between surface and groundwater occurs. Surface runoff samples and underground water were collected to determine concentrations and forms of $\mathrm{P}$ and determine their significance in $\mathrm{P}$ transport from pasture based grazing systems into water bodies.

\section{MATERIALS AND METHODS}

The study site is located in Greenbrier County in southern West Virginia and includes pastures grazed rotationally or continuously from April through October each year. In the rotational system the cattle were grazed on the site about two or three days every couple of weeks depending on availability of forage and in the continuous system the study section of pasture was available to grazing livestock throughout the entire grazing season. An ungrazed sinkhole (mowed grass, no grazing), representing landscape common to the area, was also included in the study. The soil series are Caneyville (fineloamy, mixed, active, mesic, Typic Hapludalfs) in sinkholes floors and Frederick (clayey, mixed, active, mesic, Typic Paleudult) on side slopes. The dominant forage species are tall fescue (Festuca arundinacea Schreb.) and red clover (Trifolium pratense L.). The grazing intensity of the rotationally grazed sink was 3.5 head $\cdot$ ha $^{-1}$, while the continuously grazed site was stocked at $3 \mathrm{head} \cdot \mathrm{ha}^{-1}$. Grazing cattle are a mixture of races: Angus, and Charolais constitute about $50 \%$ of the total number of cattle on both sites, and Limousin, Hereford, and Simmental make up the other $50 \%$. Cattle are moved on the study site in March (12 months old) weighing between 200-250 kg and sold in September when weight reaches 360$410 \mathrm{~kg}$. Initial soil test results show $\mathrm{pH}$ greater than 5.5, so lime was not spread most years. However, every six years the
Intermittently-grazed sinkhole

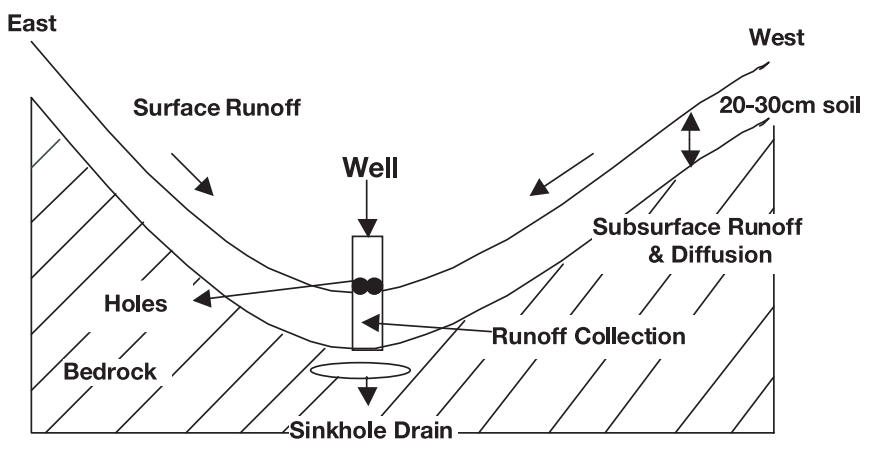

Figure 1. Topography of the sinkhole located in the rotationally grazed pasture and location of surface runoff collectors (well).

grazed sinkholes received agricultural dolomitic lime $\mathrm{CaMg}\left(\mathrm{CO}_{3}\right)_{2}$ applied at a rate of $4.94 \mathrm{Mg} \cdot \mathrm{ha}^{-1}$ in autumn. Inorganic fertilizers (ammonium nitrate, triple super phosphate, and potassium sulfate) $\mathrm{N}, \mathrm{P}$, and $\mathrm{K}$ were applied to grazed sinkholes each spring at rates of 34,40 , and $56 \mathrm{~kg} \cdot \mathrm{ha}^{-1}$, respectively. The grazed sinkholes have undergone grazing for at least 30 years. The grazed sinkholes were between 102 and $118 \mathrm{~m}$ in diameter and from 5 to $8 \mathrm{~m}$ deep. Rim locations in the sinkhole were identified $51 \mathrm{~m}$ to either side of the center and lowest point near the sinkhole drain. The nongrazed sinkhole was $30 \mathrm{~m}$ width and $3 \mathrm{~m}$ depth, with average side slope, measured from the sinkhole rims, $11.3 \pm 1.5 \%$ along east-west transects. It is the only sinkhole in the area that was never grazed or received application of mineral fertilizers.

\subsection{Sample collection}

Soil samples were collected from 8 locations at two depths $(0-5 \mathrm{~cm} ; 5-20 \mathrm{~cm})$ along a single transect (east-west) across each of the two sinkholes (four samples within three meters of the sinkhole rim and four samples within three meters of the lowest sinkhole elevation representing the sinkhole bottom). For the nongrazed sinkhole, which had a smaller diameter than the grazed sinkholes, four samples were collected within 2 meters of the sinkhole rim and four samples were taken within two meters of the lowest sinkhole elevation. Figure 1 schematically represents sinkhole profiles. Samples were airdried and ground to pass $0.15 \mathrm{~mm}$ sieve prior to analysis. Surface runoff was collected from a sinkhole in the rotationally grazed site. A 10-cm diameter capped plastic pipe (well), with holes in the pipe at the soil surface, was placed vertically in the soil at the lowest point of the sinkhole. Surface runoff after each naturally occurring runoff event was collected through the perforations in the pipe, for a total of 11 samples collected between August 1999 and August 2000. Runoff accumulated in the bared section of the well in the soil, which was collected by suction. Therefore, runoff represents storm total, and we did not measure runoff volume or variation in associated $\mathrm{P}$ concentrations over the course of individual runoff events. 


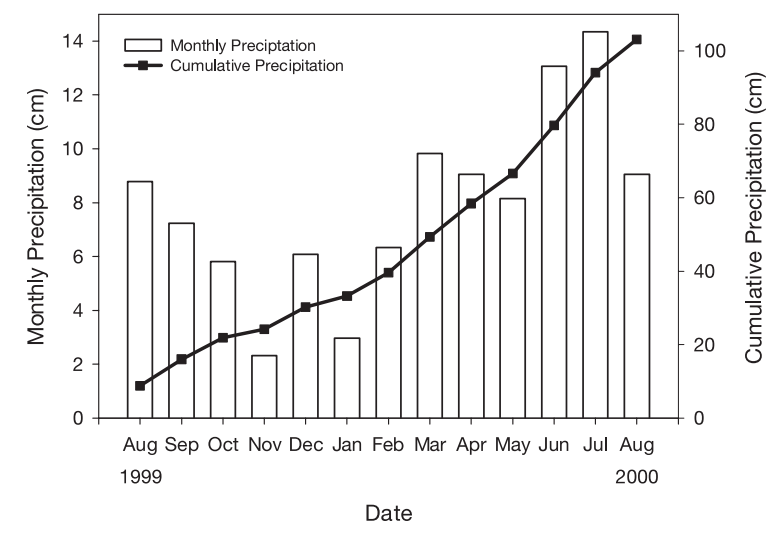

Figure 2. Monthly and cumulative precipitation for the interval August 1999 through August 2000.

Figure 2 shows average monthly and cumulative precipitation over the interval August 1999 through August, 2000.

Sinkholes in the study area drain into underground streams of the Hole Basin [1]. Samples were collected in Burns Cave, which drains the Hole Basin, on a weekly basis from August 1999 through August 2000 using an automatic sampler (ISCO Model $2700^{1}$ ) located $15 \mathrm{~m}$ inside the cave entrance. Samples were filtered immediately after collection through $0.45 \mu \mathrm{m}$ filter paper and stored frozen for $\mathrm{P}$ measurements.

\subsection{Soil extraction}

Soil samples $(0.5 \mathrm{~g})$ were transferred into $50 \mathrm{~mL}$ centrifuge tubes along with $30 \mathrm{~mL}$ of deionized water. Tubes were shaken for $16 \mathrm{~h}$ in a reciprocating shaker at 200 strokes per minute. They were then centrifuged at $3000 \mathrm{~g}$ for 15 minutes. The supernatant was filtered through Whatman No. 1 filter paper and followed by a second filtration through Pall GN-6 Metricel ${ }^{\circledR} 0.45 \mu \mathrm{m}$ membrane filters. Soil water extracts were kept cold $\left(4^{\circ} \mathrm{C}\right)$ and analyzed for DPi, MRP, TDP, and organic carbon within $24 \mathrm{~h}$ of extraction.

\subsection{Chemical analyses}

DPi in soil water extracts and samples collected from the well and lysimeters was determined by ion chromatography with suppressed conductivity (Dionex DX 500 ion chromatograph, AS14 $4 \mathrm{~mm}$ anion column). Molybdate reactive $\mathrm{P}$ (MRP) was measured on soil water extracts filtered at $0.45 \mu \mathrm{m}$ by colorimetry [18]. Total dissolved $\mathrm{P}$ (TDP) in water samples and soil extracts was measured by colorimetry on a Beckman DU-640 spectrophotometer after digestion in acidified ammonium persulphate oxidation [9]. Dissolved unreactive P (DPu) was calculated as the difference between TDP and MRP in water extracts or DPi in well samples.

Total soil $\mathrm{N}$ and $\mathrm{C}$ were determined using Carlo Erba analyzer (EA1108 CHNSO, Milan, Italy). Soil pH was determined in 1:1 soil to water ratio [31]. Dissolved organic carbon

\footnotetext{
${ }^{1}$ Use of trade or proprietary names do not imply endorsement by USDA-ARS.
}

(DOC) was measured in water extract using Total Organic Carbon Analyzer (Shimadzu TOC-V CPH/CPN, Kyoto, Japan).

\subsection{Statistical analysis}

All variables were analyzed as a randomized complete block design using the MIXED model procedure of SAS [15]. Position, grazing and depth were analyzed as fixed effects with replicate modeled as the random variable. Single-degreeof-freedom contrasts were used to compare the fixed effect means. Denominator degrees of freedom were calculated using the Satterthwaite option of MIXED analysis to determine appropriate degrees of freedom to test fixed effects and interactions of fixed effects.

\section{RESULTS}

General soil properties, such as $\mathrm{C}, \mathrm{N}$, and $\mathrm{pH}$, differed the most when nongrazed was compared to continuously grazed sites (Tab. I). Soil pH was lowest in continuously grazed compared to either the nongrazed or rotationally grazed sites (Tab. I). Soil pH was not influenced by soil depth or position in the sinkhole. Nitrogen decreased with soil depth and did not vary with position in the sinkhole (Tab. I). Soil $\mathrm{N}$ was greater in soils from the continuously grazed compared to either the rotational or nongrazed sites (Tab. I).

Total soil $\mathrm{C}$ was greater in the continuous compared to rotationally- and non-grazed sinks, and increased from the rim toward the bottom center of the sinkhole (Tab. I). Soil depth had the greatest influence on soil $\mathrm{C}$, being greater in the upper compared to the lower soil strata analyzed. The $\mathrm{C}: \mathrm{N}$ ratio was greater at the bottom compared to sinkhole rim in the continuously compared to rotationally- and non-grazed sinkholes. Electroconductivity (EC) was greater in the upper compared to lower soil layer irrespective of grazing management or position (Tab. I).

DPi was not detected in the nongrazed sink regardless of soil depth and reflects the absence of fertilizer application and the lack of nutrient recycling that could be caused by grazing livestock. Some DPi was detected in the upper layer of soil in rotationally- and continuously-grazed sinkholes (Tab. II) and greater at the sinkhole bottom compared to the rim and greater in the continuous compared to the rotationally grazed pasture.

Trends in TDP and DPu were similar to those of DPi. DPu concentrations decreased with soil depth in grazed sinkholes and were greater in the uppermost soil layer of continuous compared to rotationally- or the non-grazed sinkhole. DPu represented a greater proportion of TDP with increasing soil depth in rotational and continuously grazed sinks and tended to be greater (not significant at $P<0.05$ ) at the bottom of the rotational and continuously grazed sinks compared to the rim (Tab. II). The proportion of DPu tended to be greater $(P<$ $0.01)$ in grazed compared to non-grazed sinks at soil depths greater than $5 \mathrm{~cm}$.

DOC was greater in the upper compared to the lower soil layer, and was greater in continuously compared to non-grazed sites (Tab. II). Concentrations increased from the 
Table I. The influence of grazing [non (N), rotational (I) or continuous (C)], landscape position [sinkhole rim (R) or bottom (B)] and soil depth [upper (U) 0-5 cm; lower (L) 5-20 cm] on soil N, C the C:N ratio, pH and electroconductivity (EC). Values are the means of four replicate samples and analysis of variance and single degree-of-freedom contrasts for treatment influences on each parameter.

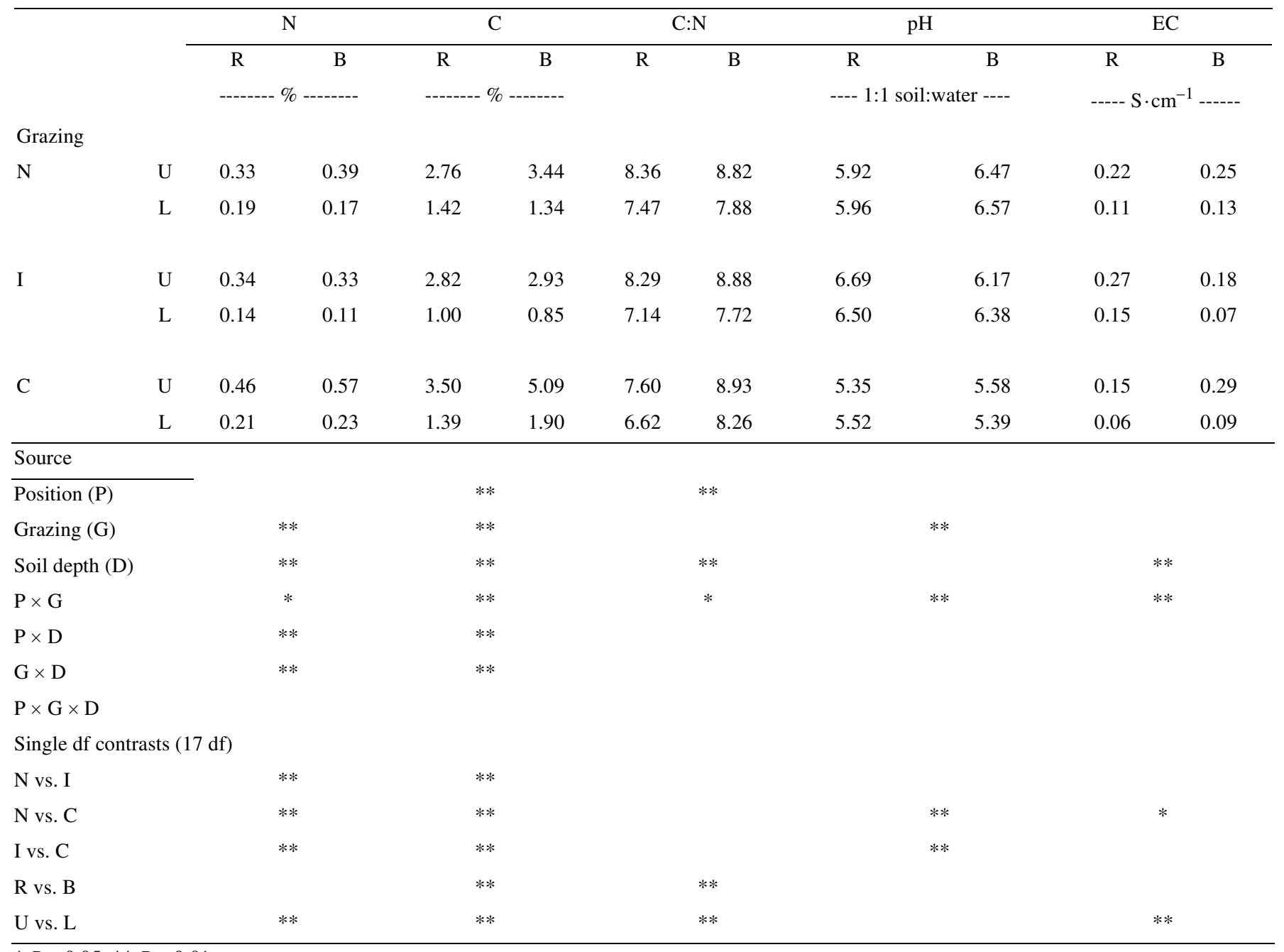

$* P<0.05 ; * * P<0.01$.

sinkhole rim to the bottom. The distribution of DOC at different positions in the sinkholes and at differing soil depths was similar to that of DPu (Fig. 3) and for TDP-DPi. The relationship between DPu and DOC was strong $(r=0.80, P<0.01)$ despite variation in grazing management, location within the sinkhole and soil depth.

Eleven naturally occurring storm events were sampled between August 1999 and August 2000. Total dissolved phosphorus in surface runoff was expressed as DPi and DPu (Fig. 4). Concentrations of DPi were higher than those of DPu for all events, with the exception of those occurring on 31 July and 11 August 2000. Dissolved unreactive phosphorus, as a fraction of TDP in surface runoff, varied from $1 \%$ on 11 January 2000 to $58 \%$ on 31 July 2000 , and averaged $27 \pm 19 \%$ of TDP for the 11 storm events measured. Most of the TDP in water samples collected from a spring flowing out of the Burns Cave system underlying the experiment site [1], was in the form of $\mathrm{DPu}$ (Fig. 5). Exceptions were samples collected in autumn of 1999 (Sept., Oct., and Nov.), when some DPi was detected.

\section{DISCUSSION}

\subsection{Nutrient inputs in pasture}

Data were collected from seasonally grazed, permanent pastures on a farm where beef cattle were raised for at least 30 years. As a result, in addition to annual mineral fertilization, $\mathrm{N}, \mathrm{C}$ and $\mathrm{P}$ are introduced to the soil surface in the form of livestock manure [13]. Concentrations of N, C and P were greater when pasture was continuously grazed compared to rotationally- or non-grazed. A larger proportion of $\mathrm{C}$ compared to $\mathrm{N}$ mineralizes with manure decomposition, and leaches deeper into the soil profile decreasing the $\mathrm{C}: \mathrm{N}$ ratio with soil depth (Tab. I). 
Table II. The influence of grazing [non (N), rotational (I) or continuous (C)], landscape position [sinkhole rim (R) or bottom (B)] and soil depth [upper (U) 0-5 cm; lower (L) 5-20 cm] on dissolved unreactive P (DPu), dissolved inorganic P (DPi), molybdate reactive P (MRP), total dissolved P (TDP), and dissolved organic C (DOC). Values are the means of four replicate samples and analysis of variance and single degreeof-freedom contrasts for treatment influences on each parameter.

\begin{tabular}{|c|c|c|c|c|c|c|c|c|c|}
\hline \multicolumn{2}{|c|}{ DPi } & \multicolumn{2}{|c|}{$\mathrm{DPu}$} & \multicolumn{2}{|c|}{ MRP } & \multicolumn{2}{|c|}{ TDP } & \multicolumn{2}{|c|}{ DOC } \\
\hline $\mathrm{R}$ & B & $\mathrm{R}$ & B & $\mathrm{R}$ & B & $\mathrm{R}$ & B & $\mathrm{R}$ & B \\
\hline
\end{tabular}

\begin{tabular}{|c|c|c|c|c|c|c|c|c|c|c|c|}
\hline \multicolumn{12}{|c|}{ Grazing } \\
\hline \multirow[t]{2}{*}{$\mathrm{N}$} & $\mathrm{U}$ & $\mathrm{nd} \ddagger$ & nd & 9.50 & 16.51 & 17.96 & 12.83 & 27.46 & 29.33 & 758 & 724 \\
\hline & $\mathrm{L}$ & nd & nd & 9.11 & 11.65 & 6.84 & 6.09 & 15.95 & 17.71 & 508 & 424 \\
\hline \multirow[t]{2}{*}{ I } & $\mathrm{U}$ & 2.75 & 19.50 & 10.60 & 11.00 & 6.25 & 30.55 & 16.85 & 41.53 & 857 & 964 \\
\hline & $\mathrm{L}$ & nd & nd & 5.63 & 5.53 & 1.15 & 1.73 & 6.78 & 7.25 & 450 & 387 \\
\hline \multirow[t]{2}{*}{$\mathrm{C}$} & $\mathrm{U}$ & 5.75 & 36.25 & 19.85 & 25.55 & 9.98 & 50.78 & 29.85 & 76.30 & 1082 & 1736 \\
\hline & $\mathrm{L}$ & nd & nd & 10.05 & 11.43 & 0.85 & 2.20 & 10.88 & 13.63 & 515 & 644 \\
\hline
\end{tabular}

\begin{tabular}{|c|c|c|c|c|c|}
\hline Source & & & & & \\
\hline Position (P) & $* *$ & & $* *$ & $* *$ & \\
\hline Grazing (G) & $* *$ & $* *$ & $* *$ & $* *$ & $* *$ \\
\hline Soil depth (D) & $* *$ & $* *$ & $* *$ & $* *$ & $* *$ \\
\hline$P \times G$ & $* *$ & & $* *$ & $* *$ & $*$ \\
\hline $\mathrm{P} \times \mathrm{D}$ & $* *$ & & $* *$ & $* *$ & $*$ \\
\hline $\mathrm{G} \times \mathrm{D}$ & $* *$ & $*$ & $* *$ & $* *$ & $* *$ \\
\hline $\mathrm{P} \times \mathrm{G} \times \mathrm{D}$ & $* *$ & & $* *$ & $* *$ & \\
\hline \multicolumn{6}{|c|}{ Single df contrasts ( $17 \mathrm{df})$} \\
\hline $\mathrm{N}$ vs. I & $* *$ & & & & \\
\hline $\mathrm{N}$ vs. $\mathrm{C}$ & $* *$ & $*$ & $* *$ & $* *$ & $* *$ \\
\hline I vs. C & $* *$ & $* *$ & $* *$ & $* *$ & $* *$ \\
\hline R vs. B & $* *$ & & $* *$ & $* *$ & \\
\hline U vs. L & $* *$ & $* *$ & $* *$ & $* *$ & $* *$ \\
\hline
\end{tabular}

$* P<0.05 ; * * P<0.01$.

$\ddagger=$ not detected.

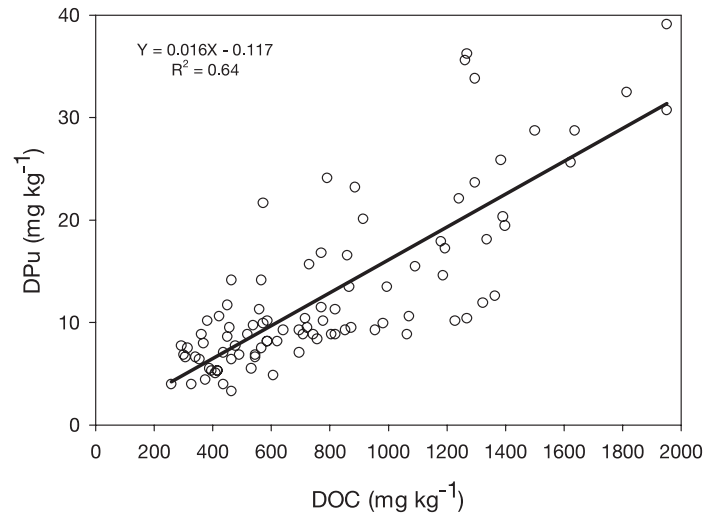

Figure 3. Relationship between dissolved unreactive $\mathrm{P}(\mathrm{DPu})$ and dissolved organic carbon (DOC) in soil water extract.
Grazing and subsequent recycling of nutrients from manure, may lead to greater concentrations of water-soluble $\mathrm{P}$ in the surface layer of soil when compared to nongrazed sites. An estimated $18 \mathrm{~kg} \mathrm{P} \cdot \mathrm{ha}^{-1}$ was returned annually in manure at the experiment site, based on mineral analysis of the manure and stocking rate of grazers (J.P.S. Neel, personal communication). Phosphorus concentrations in the uppermost soil layer present the greatest environmental concern, since $\mathrm{P}$, especially that associated with manure can move by or be released to surface runoff [26].

\section{2. $P$ concentration and forms in soil water extracts}

The proportion of MRP and DPi relative to DPu decreased with soil depth, suggesting that DPu was the most mobile form of $\mathrm{P}$ in pastures, or that some transformation occurring in the 


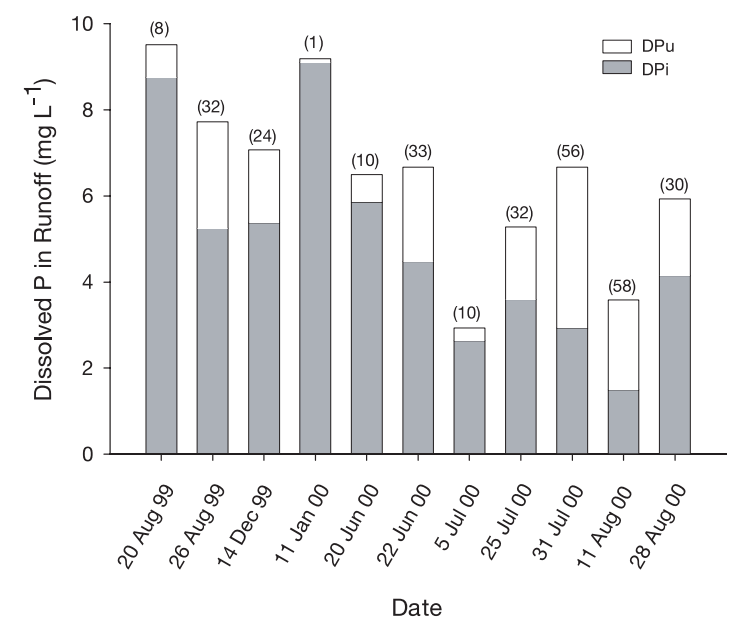

Figure 4. Dissolved unreactive $\mathrm{P}(\mathrm{DPu})$ and inorganic $\mathrm{P}(\mathrm{DPi})$ in water runoff in samples collected from the rotationally grazed sinkhole. Numbers in parentheses are percent of $\mathrm{Pu}$ of total in water runoff.

soil might cause a shift in $\mathrm{P}$ form. Our data agree with some greenhouse and field experiments where more than $60 \%$ of TDP in soil solution and leachate is dissolved unreactive P [6, 25]. The large proportion of $\mathrm{DPu}$ calculated in this study in soil water extracts (Tab. II) could have also resulted, in addition to impact of grazing, from drying and rewetting of the soil for extraction. Turner and Haygarth [33] reported that rewetting of soil dried at $30{ }^{\circ} \mathrm{C}$ resulted in the release of large amounts of water soluble organic $\mathrm{P}$. This was attributed to direct release of phosphorus from the soil microbial bio-mass, because microbes can be killed by osmotic shock and cell rupture when rapid rehydration follows a period of drying [33]. However as the amount of microbial biomass is usually lower in the $5-20 \mathrm{~cm}$ than in the $0-5 \mathrm{~cm}$, the proportionally higher $\mathrm{DPu}$ content observed in the deeper horizon can not be only explained by the release of $\mathrm{P}$ from the soil microbial biomass.

We found that a considerable amount of $\mathrm{P}$ measured as MRP was not DPi, and that DPi was not detected in the lower soil layer. Similar differences between inorganic phosphorus (DPi) determined by ion-chromatography and molybdate reaction were also reported for water-soil extraction [30], while inorganic phosphorus was reported to contribute to more than $97 \%$ of the MRP component as measured in overland flow in irrigated grazing system [12]. These differences can be explained by the presence of organic $\mathrm{P}$ compounds in the solution and/or the presence of $\mathrm{P}$ containing colloids that can be hydrolyzed by the acidic medium used to determine MRP whereas these forms are not hydrolyzed during the ion chromatographic analyses [2,6]. The $\mathrm{DPu}$ fraction of our soil water extract and overland flow samples may therefore contain some organic and colloidal P [3, 5, 25, 30].

The strong correlation of DOC with $\mathrm{DPu}$ suggests that manure or plant litter is a likely source of $\mathrm{P}$ since it is the major source of organic material deposited on the grazed grasslands. Plant litter is also higher in our grazed system than in the non grazed system as it is affected by the higher fertilization rate

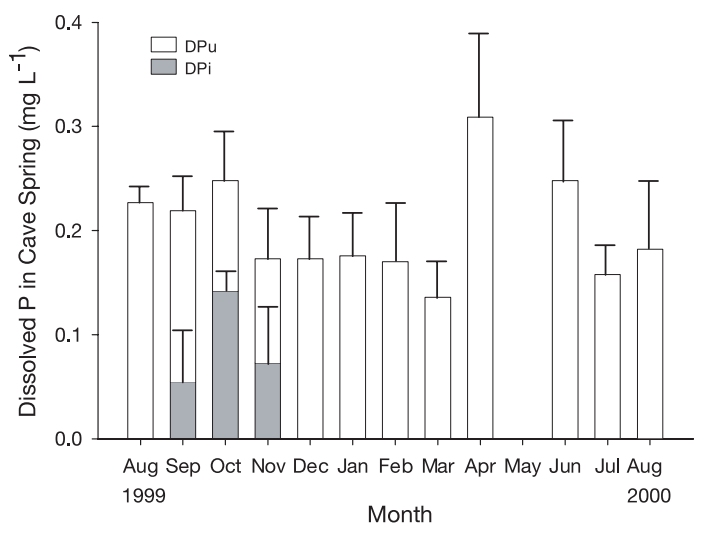

Figure 5. Dissolved unreactive $\mathrm{P}(\mathrm{DPu})$ and inorganic $\mathrm{P}(\mathrm{DPi})$ in outflow of the karst aquifer underlying the experiment site. Bars are standard errors.

in the grazed system. A number of water-soluble compounds rich in $\mathrm{P}$ such as, orthophosphate, glucose-6-phosphate, choline phosphate, and adenosine triphosphate, result from manure decomposition [16]. Some of these compounds might not be bound tightly onto soil surfaces when compared to inorganic orthophosphate [21] and are thus more mobile. More than $90 \%$ of the $\mathrm{P}$ in leachate from manure applied to soil columns was in the form of organic and/or organically-bound $\mathrm{P}$ [3]. Our results also suggest that water-soluble $\mathrm{P}$ moves through the soil profile in conjunction with organic compounds in a pasture system, especially with decomposition and recycling of manure.

\section{3. $P$ concentration and forms in runoff and source water}

Concentrations of $\mathrm{P}$, regardless of form (DPi or $\mathrm{DPu}$ ), occurring in runoff (Fig. 4) were far greater than critical levels of dissolved $\mathrm{P}$ according to U.S. EPA guidelines of 0.1 and $0.05 \mathrm{mg} \mathrm{P} \cdot \mathrm{L}^{-1}$ for streams and lakes, respectively [27]. Dissolved $\mathrm{P}$ concentrations (DPi and $\mathrm{DPu}$ ) observed in our study were higher (up to about $10 \mathrm{mg} \cdot \mathrm{L}^{-1}$ ) than most reported $\mathrm{P}$ values in runoff in similar agricultural systems. The combination effects of high $\mathrm{P}$ concentration in the most upper soil layer, manure deposition on the surface, slope (up to 27\%), and inorganic fertilization may have increased the mobility and movement of $\mathrm{P}$ in runoff. The highest reported $\mathrm{P}$ concentration (MRP) in runoff from grazing system in the UK was $1.773 \mathrm{mg} \cdot \mathrm{L}^{-1}$, which occurred immediately after application of triple super phosphate [6] and similar concentrations were reported in the US [7] and Australia [12]. Sharpley and Moyer [29] noted that inorganic P $(77 \%)$ was the principal water-soluble $\mathrm{P}$ form in dairy manure, and was reflected in the ratio of Pi:Po leached during rainfall simulation experiments. The potential for $\mathrm{P}$ to leach from manure was most closely related to water extractable inorganic P [29]. The contrasting differences in phosphorus species dominating the composition of runoff (dominated by DPi) and stream water (dominated by $\mathrm{DPu}$ ) are very interesting findings (Figs. 4, 5). Most water 
feeding into underground water streams is from water percolating through the soil profile containing $\mathrm{P}$ forms with a greater mobility in the soil compared to inorganic $\mathrm{P}$ [3]. Considering the geochemistry underlying karst environment rich in $\mathrm{Ca}$, inorganic orthophosphate precipitates readily in water [32], explaining the low or undetectable DPi concentrations in underground stream water (Fig. 5). Another factor that might have contributed to little detection of DPi in runoff and underground stream water in our study is the fact that water samples were frozen in polyethylene containers prior to analysis due to technical problems in our laboratory settings. Freezing and storage of water samples in polyethylene containers was shown to greatly decrease both orthophosphate and MRP, and even to a greater extent if water samples contained high concentrations of $\mathrm{Ca}$ and DOC [4]. Unfortunately, both elements may have existed in our frozen samples of runoff and underground stream water (Tab. I, Fig. 3).

We showed that DPi decreased more than did DPu with increased soil depth, suggesting that DPu was a mobile form of P. Landscape position appears to be linked with changes in dissolved $\mathrm{P}$ from sinkhole rim toward the bottom center of sinkholes. The gradual increase in $\mathrm{P}$ concentrations from the rim toward the bottom and center of a sinkhole indicates the likelihood of surface runoff, probably in the form of manure and $\mathrm{P}$-enriched sediment. We observed cattle grazing behavior and manure deposition and found that cattle did not consistently congregate in the bottom of sinkholes, therefore there was little likelihood that direct deposition of cattle manure contributed to greater $\mathrm{P}$ values near the sinkhole center (data not shown). Phosphorus leaching in porous karst landscape was facilitated by $\mathrm{DPu}$, which comprised a significant fraction of TDP in soil-water extracts and underground stream water samples. Characterization of $\mathrm{DPu}$ fractions in soil should improve understanding of Po leaching mechanisms from pasture.

Acknowledgment: The use of trade names does not imply endorsement by the US Department of Agriculture. We thank R. Lester, D. Hall, T. Robertson, E. Lester and J. Ruckle for technical assistance and continuous help during the course of the project. The hospitality and cooperation of the Lloyd and Lonnie Burns families were greatly appreciated.

\section{REFERENCES}

[1] Boyer D.G., Pasquarel G.C., Nitrate concentrations in karst springs in an extensively grazed area, Water Res. Bull. 31 (1995) 729-736.

[2] Broberg O., Petterson K., Analytical determination of orthophosphate in water, Hydrobiologia 170 (1988) 45-59.

[3] Chardon W.J., Oenema O., Castilho P. del, Vriesema R., Japenga J., Blaauw D., Organic phosphorus in solution and leachates from soils treated with animal slurries, J. Environ. Qual. 26 (1997) 372 378.

[4] Haygarth P.M., Ashby C.D., Jarvis S.C., Short-term changes in the molybdate reactive phosphorus of stored soil waters, Environ. Qual. 24 (1995) 1133-1140.

[5] Haygarth P.M., Warwick M.S., House W.A., Size distribution of colloidal molybdate reactive phosphorus in river water and soil solution, Water Res. 31 (1997) 439-448.
[6] Haygarth P.M., Hepworth L., Jarvis S.C., Forms of phosphorus transfer in hydrological pathways from soil under grazed grassland, Eur. J. Soil Sci. 49 (1998) 65-72.

[7] Edwards D.R., Hutchens T.K., Rhodes R.W., Larson B.T., Dunn L., Quality of runoff from plots with simulated grazing, J. Am. Water Res. Assoc. 36 (2000) 1063-1073.

[8] Eghball B., Binford G.D., Baltensperger D., Phosphorus movement and adsorption in a soil receiving long-term manure and fertilizer application, J. Environ. Qual. 5 (1996) 1339-1343.

[9] Environmental Protection Agency, Methods of chemical analysis of water and wastes, Environmental Protection Agency, Cincinnati, Ohio, USA, 1971.

[10] Espinosa M., Turner B.L., Haygarth P.M., Pre-concentration and separation of trace phosphorus compounds in soil leachate, J. Environ. Qual. 28 (1999) 1497-1504.

[11] Frossard E., Stewart J.W.B., Arnaud R.J., Distribution and mobility of phosphorus in grassland and forest soils of Saskatchewan, Can. J. Soil Sci. 69 (1989) 401-416.

[12] Halliwell D., Coventry J., Nash D., Inorganic monophosphate determination in overland flow from irrigated grazing systems, Int. J. Environ. Anal. Chem. 76 (2000) 77-87.

[13] Haynes R.J., Williams P.H., Nutrient cycling and soil fertility in the grazed pasture ecosystem, Adv. Agron. 49 (1993) 119-199.

[14] Johnston A.E., Poulton P.R., The role of phosphorus in crop production and soil fertility: 150 years of field experiments at Rothamsted, United Kingdom, in: Schultz J.J. (Ed.), Phosphate fertilizer and the environment, International Fertilizer Development Center, Florida, USA, 1992, pp. 45-63.

[15] Littell R.C., Milliken G.A., Stroup W.W., Wolfinger R.D., SAS ${ }^{\circledR}$ systems for mixed models, Cary, NC, SAS Institute Inc, USA, 1996

[16] Magid J., Tiessen H., Condorn L.M., Dynamics of organic phosphorus in soils under natural and agricultural ecosystems, in: Piccolo A. (Ed.), Humic substances in terrestrial ecosystems, Elsevier Science, Dordrecht, 1996, pp. 429-466.

[17] Mozaffari M., Sims J.T., Phosphorus availability and sorption in an Atlantic Coastal Plain watershed dominated by animal-based agriculture, Soil Sci. 157 (1994) 97-107.

[18] Murphy J., Riley J.P., A modified single solution method for determination of phosphate in natural waters, Anal. Chim. Acta 27 (1962) 31-36.

[19] Nash D.M., Halliwell D.J., Fertilizers and phosphorus loss from productive grazing systems, Aust. J. Soil Res. 37 (1999) 403-429.

[20] Nash D., Mardoch C., Phosphorus leaching from cattle dung and fertilizer in a karsozem, in: Australian and New Zealand National Soils Conference 1996, Soil Science-Raising the Profile, Australian Society of Soil Science Inc., Parkville, 1996, pp. 189190.

[21] Parfitt R.L., Anion adsorption by soil and soil material, Adv. Agron. 30 (1978) 1-50.

[22] Perrott K.W., Sarathchandra S.U., Waller J.E., Seasonal storage and release of phosphorus and potassium by organic matter and the microbial biomass in a high producing pastoral soil, Aust. J. Soil Res. 28 (1990) 593-608.

[23] Ron Vaz M.D., Edwards A.C., Shand C.A., Cresser M.S., Phosphorus fractions in soil solution: Influence of soil acidity and fertilizer additions, Plant and Soil 148 (1993) 175-183.

[24] Ryden J.C., Syers J.K., Harris R.F., Phosphorus in runoff and streams, Adv. Agron. 25 (1973) 1-45.

[25] Shand C.A., Macklon A.E.S., Edwards A.C., Smith S., Inorganic and organic $\mathrm{P}$ in soil solutions from three upland soils: 1. Effect of soil solution extraction conditions, soil type and season, Plant and Soil 159 (1994) 255-264.

[26] Sharpley A.N., Depth of surface soil-runoff interaction as affected by rainfall, soil slope, and management, Soil Sci. Soc. Am. J. 49 (1985) 1010-1015. 
[27] Sharpley A.N., Chapra S.C., Wedepohl R., Sims J.T., Daniel T.C., Reddy K.R., Managing agricultural phosphorus for protection of surface waters: Issues and options, J. Environ. Qual. 23 (1994) 437-451

[28] Sharpley A.N., Robinson J.S., Smith S.J., Phosphorus dynamics in agricultural soils and effects on water quality, Geoderma 67 (1995) $1-15$.

[29] Sharpley A., Moyer B., Phosphorus forms in manure and compost and their release during simulated rainfall, J. Environ. Qual. 29 (2000) 1462-1469.

[30] Sinaj S., Mächler F., Frossard E., Faïsse C., Oberson A., Morel C. Interferences of colloidal particles in the determination of orthophosphate concentrations in soil water extracts, Commun. Soil Sci. Plant Anal. 29 (1998) 1091-1105.
[31] Sparks D.L., Methods of soil analysis. Part 3- Chemical methods, SSSA Book Series No. 5, Madison, WI, USA, 1996.

[32] Turner B.L., Haygarth P.M., Phosphorus forms and concentrations in leachate under four grassland soil types, Soil Sci. Soc. Am. J. 64 (2000) 1090-1097.

[33] Turner B.L., Haygarth P.M., Phosphorus solublization in rewetted soils, Nature 411 (2001) 258

[34] Turner B.L., McKelvie I.D., Haygarth P.M., Characterisation of water-extractable soil organic phosphorus by phosphatase hydrolysis, Soil Biol. Biochem. 34 (2002) 27-35.

[35] US Geological Survey, Data from Selected US Geological Survey National Stream Water Quality Monitoring Networks (WQN). US Geological Survey, Digital Data Series DDS-37, USA, 1996. 